\title{
The Future of European Union and Some of the Challenges it has to Face
}

\author{
Mrs. Zemaida Kastrati Mozali, PhD
}

Department of Foreign Relations

Parliament of Albania

Doi:10.5901/mjss.2013.v4n6p453

Abstract

On the long road of more than a century of the European Union, it is very important for everyone to understand that European Union is not anymore the so-called "exclusive club". The actual number of 27 members confirms that, despite the many, many problems the united Europe has to face with, is open and accessible to any European country that fulfills the Copenhagen criteria, i.e. the criteria of democracy. After a short description of the reason why a European Union was created, my paper mainly is focused on the problems which have accompanied this organism since its beginnings. The challenges are innumerous, mainly focused on the domestic economic crisis, foreign policy, monetary union, security, enlargements, etc; these are some of the problems European Union has to address in order for it to continue to exist and be successful. We should never forget that, since its beginning, EU has passed through some enlargements and it has become the aspiration for many countries, including the Balkan countries. But now, it seems that this enlargement has "frozen" somehow. So, it is very important for us to know and to make clear of the perspective of the European Union: Will European Union continue to enlarge and accept other countries, or it has to stop and address the many problems within it? Where will this Union "stop"? ${ }^{1}$ The paper will be finished with some conclusions or suggestions I can give from my perspective of an individual of a "would be European" country.

\section{Historical reason for a European Union}

Historical memory is the term which we often see in political writings, or hear in political discourses. This means, if we want to understand the present, we have to have a clear understanding of the past. In the case of European Union, one has to go deep into the origin of this organism. This means many years ago, "Seventy years ago, Europe was being torn apart by its second catastrophic conflict in a generation, says David Cameron. A war which saw the streets of European cities strewn with rubble. The skies of London lit by flames night after night. And millions dead across the world in the battle for peace and liberty." (This version of the speech given by David Cameron at Bloomberg, is as written not as spoken.) $)^{2}$

Without forgetting that the idea for creating a union of European states originates since the XIX century, the postwar world made it absolutely a necessity. "...What they did when they started this project. They had just come from some Great War, II World War, from its destruction, death, the Holocaust, hatred, totalitarianism, hunger, racism..." After this experience, they said "Let's see if we can avoid entering into war again, let's join our industries of mining, coal and steel, are not able to turn them in industries that produce weapons used against each other.." So they sacrifice their principles and absolute independence of nation states, for the sake of economic development and, above all, cooperation between previously warring states; in a sense, Europe of 1945 marked the beginning of "Second Half twentieth Century" (Daniel R. Brower, 1999).

\section{Enlargements of EU and some problems related to them}

After 1945, European Union has gone through five enlargements, each one bringing "inside" the EU new states with new problems. The question "widening or deepening" has been a persisting one, because it was almost impossible for the EU to "stop" and try to "put things in order" within it, because in meantime, other states were approaching with requests for membership.

\footnotetext{
${ }^{1}$ The President of Morocco, in an international event has asked some leaders of EU: When can we apply for EU membership?" This means, the geographical and physical criteria of membership should be taken "for granted" from the countries that aspire to be part of it. 2 https://www.gov.uk/government/news/david-camerons-eu-speech--2
} 
"Enlargement is both a historical opportunity and an obligation for the European Union and therefore one of its highest priorities. My aim is to strike the right balance between two objektives in the enlargement process: speed and quality. Our success in concluding the historic undertaking on which we have embarked together with the candidate countries will depend on the intensity and quality of our joint work" declared Gunter Verheugen, Member of European Commission responsible for enlargement (http://europa.eu.int/comm/enlargement/overview.htm)

Enlargement(s) of the EU is a very interesting topic, which deserves a very deep analysis. This is because if we refer to popular support, this is so important, and should be analyzed as well. This is because of the feelings and reactions, expressed in the key moments are significative. Let we remember here the "No" of Norway to become member of European Community in 1972, or the "No" of Denmark versus Maastricht Treaty, or the "almost No" of the France in relation to this referendum, or the ratification of the Nice Agreement, which did not without difficulty. Thus, in Ireland it was rejected by a referendum, with a very low participation in the vote.

Without examining in detail the non-Irish vote, which in fact has to do with policy of governments that withdraw states in support of integration, there may be extended the fact that the new agreement to bring the EU enlargement will certainly be possible to get approved. Perhaps, by theory, it is clear that an agreement becomes effective only after approval by all states, but it certainly can not become an obstacle to EU enlargement.

Such cases have been other times as well. Thus, there has been rejected the Mastihtit Treaty from Denmark in 1992 through a referendum, but through negotiations, additional protocols and exceptional rules, there has been reached the YES with the second referendum. That, even in a Member State, which, given the skepticism towards the EU in the broad strata of the population, it is considered a more difficult partner than Ireland. So, in many cases the popular answer has been "No" with regard to the steps or different moments. This is related to many reasons. Not wanting to pass on more details, I think that economic problem is very strong to bring a "resistance" in the moments when given the opportunity. Many Europeans are unhappy with taxes that pay. While Brussels seems very far from their demands and problems and in most of cases "inaccessible", referring to the bureaucracy, or eurocracy and that does not represent directly requirements and their daily problems. When a Norwegian was asked "Why you voted against membership in the EU?" he said: "Now our government is big enough. Why should she become greater? Oslo is already far away, why go further up in Brussels? (Rourke 2000). "This is a reason that has to do with what a big and a "far from citizens" government is not preferred by them. On the other hand, Member States politicians have doubts about their loss of power in favor of Eurocrats.

Of the same importance it is the fact that the citizens of these states are concerned in the recent times because of the increasing power of the so-called "eurocrats" over their lives. The citizens have the power to draw the national politicians out of the offices through national elections, but the "eurocrats" seem to be away from this power of citizens, although after 1979 all over Europe the voters can vote directly their representatives in European Parliament. And, the power of the Parliament has been increasing and increasing (Goldsteing, J. 2001).

I remember a friend of mine, a Norwegian man to say "Why we should enter the EU, while we do have "our fish and oil", so the economic reason, which is the key reason. I also remember the case of Malta, where the citizens voted against the membership, with the argument that "We don't need to enter a family where the revenues are lower than ours".3 So, economic prosperity is a very strong reason to have the support of the Europeans. Whereas, despite all I have mentioned, the popular support has depended on the specific time and specifics of the enlargements. According to Joh Rourkes (2000) the reliance on average has increased from 50\% in 1980 to $70 \%$ in 1989-1991, and falling back to $50 \%$ in 2000-2001. It therefore depends on the time of enlargements, which adds the differences to the common economy. When there were the first 6 countries, there was not a big difference between their economies. With the entering of the other countries with a lower economic level, the average falls, thus bringing immediate reaction of the citizen. Also the differences in GDP per capita among the EU member states are extremely large. Only Denmark and Poland have GDP respectively $\$ 29,900$ and $\$ 2,900$, thus bringing a "perturbation" in the minds and reactions of European citizens. We should not forget that when Greece, Spain and Portugal joined EU, for a period of time, these three countries, plus Ireland were called "the four poorest" within the EU. And, if it was needed, at least 25 billion USD annually in economic aid given to these "poor" and to be entered in a monetary union, much more is needed for other poorer countries which have entered later the EU..

Likewise there is a great fear as to "free arm" of work, prevailing from the EU newcomers. This has caused many problems and has increased what we call "antieuropianism". I should also mention what has come as a result of

${ }^{3}$ The author has been present in Malta in such a day, which did become a celebrating day by saying No to the membership into European Union. 
monetary integration, i.e. EURO. Even at this point there have been many reactions as there was always the fear that the introduction of a single currency can bring many problems in the economies of different countries, as it has already brought, namely the growth of different prices, but especially the petroleum and imports. Despite continuing efforts to deepen European integration in the field of monetary, fiscal, as part of the ever-increasing economic integration, which would logically lead to political integration, there are stil countries where the common currency Euro is not in use. Thus, Great Britain, Denmark and Sweden still have their coins in circulation and use, so they are not yet in the Eurozone. Even today, eleven years after the introduction of the Euro (of January 2002), although the common currency is a competitive currency in international financial markets, there is still dissatisfaction in Europeans, who complain that the Euro has destroyed all parameters of their lives, the economy has declined since its entry, and so on.

\section{The future of European Union. Some of the problems and challenges}

The European economic crisis is already a reality of more than four years. Although it has, in a way, ceased making headlines, yet it is a fact that there is no economic growth in most of European countries, there is high percentage of unemployment and falling incomes to much of the continent - with little prospect of short-term relief. Furthermore, now comes fresh evidence that hardship is having political repercussions: A Pew Research Global Attitudes Project survey documents "a crisis of confidence in the European project," in which Europeans' "faith in the European Union as an institution has fallen sharply."4

National and political identities are some of the factors related to the future of EU. Thus, many Europeans call themselves as such, while many others identify with their country. There are others who show both. It actually does not matter, it is important to continue to cultivate "Euronacionalism", while there is room for storage of what it is called "national identity". Such recommendations may come easily to light from a Balkan country, a Balkan person or a "wouldbe European" country, such as Albania, where seems rather difficult to give up easily from roots and identity. I am sure this is not that easy also in the states of "old" in Europe, which, ultimately, have even more reasons to be proud and not to relinquish their national identities. However, it is important to be oriented towards a common identity, maintaining and evaluating diversity. With more than half a century of integration has had an impact on European history and mentality of Europeans. The governments of European countries are more than aware that the "age" of absolute sovereignty has already disappeared and only through unitification of the powers and following a destiny henceforward shared", (cited from ECSC Treaty) ${ }^{5}$ it would be possible for their nations to make further progress in a common European family.

Inner and outer safeties are two issues that can be considered as "hot potatoes" for the world in general and the EU as part of it. Meanwhile, terrorism is another threat to Europe and it should be considered more as a challenge to be overcome. In other words, the European Union has to fight terrorism and organized crime, which means that police forces of all European countries need to work together. One of the new challenges Europe is to make Europe an area of freedom, security and justice where each have equal access to justice and should be equally protected by the law.

Balkan region and regional cooperation are some critical challenges the European Union has to go through. A strategy to forward integration in the region should be set a clear objective. Without such a specific plan, definite and detailed objectives, the integration of the Balkans, after the Croatia in the 2013 , will remain only theory and rhetoric. This plan should be double sides. On the one hand, the European countries should meet Copenhagen criteria as quickly and smoothly as possible. On the other hand, from the EU should come a good plan, possibly avoiding rhetoric "Europe's doors are open to the Balkans". This, because while Balkan countries were promised a place in the EU, but without a exact date, despite the problems Europe itself is facing.

EU faces risks and serious situation, perhaps unexpected and unaffordable even for itself. It is obvious and almost inevitable that European bureaucracy has began to hold back the structure and there is a real risk that the EU will be embedded in rivalries intra-and inter-organizational as well as competition. (Aberbach, J.D.Putnam, R.D., and Rockman, B. A.,1981). At the same time, as I' have already mentioned, it is configured a kind of attitude "wait-and-see" 'wait-andsee' in many governments in the region, often neglecting the fact that primary responsibility lies within those countries.

\section{Conclusions}

Integration has overcome old animosities between European countries. Attitudes of superiority and the use of force to

4 http://articles.washingtonpost.com/2013-05-15/opinions/39281707_1_european-unity-european-union-france

${ }^{5} \mathrm{http}: / /$ europa.eu/about-eu/basic-information/decision-making/treaties/index_en.htm 
settle international differences have been replaced by "community method" of working together. This approach, which balances national interests with those of common and national diversity while respecting the identity of EU, is valid today as ever.

The year 2013 will be "a time for realism and ambition in Europe". ${ }^{6}$ The consequences of the economic crisis that is straining the political and social fabric of the European Union (EU) will continue to be felt. But this is no excuse for failing to make a strong case for Europe as part of the solution to current woes, not as part of the problem.

From my point of view, from my position of a citizen of Albania, which aspires to become member of European Union one day, I would like to conclude, by referring to the words of Mr. Helmut Kohl, the German Chancellor of that time, who, direct after the Maastricht Treaty, said: "it has become possible the fulfillment of a dream"...to end with "the road of European integration is irreversible" (John T. Rourke, 2000)

Mr. Pedro Solbes, the President of FRIDE refers to the conferral of the Nobel peace prize to the EU in 2012, a fact that brought recognition for its success in bringing peace and prosperity to Europe; but, according to Mr. Solbes, " the Union also has a responsibility to consolidate these achievements and extend them to other regions, in 2013 and beyond" ( www.fride.org).

\section{References}

Aberbach, J.D.Putnam, R.D., and Rockman, B. A. (1981). Bureaucrats and Politicians in Western Democracies, Cambridge, MA: Harvard University Press.

Joshua S. Goldshtein, International Relations, Marredhenjet Nderkombetare, Integrimi, Bashkimi Europian, Shtepia Botuese Dituria, 2001, p. 420-430

John McCormick, The European Union, Politics and Policies, Fourth Edition, Copyright 2008 by Westview Press

John T. Rourke, Regional IGOs: Focus on the European Union, World Politics, International Politics on the World Stage. Brief. Third Edition, Dushkin McGraw-Hill, 2000, p.169

Daniel R. Brower, The World in the Twentieth Century, From Empires to Nations, (4thedition, 1999). The West and the Soviet Union in the Cold War, 1953-1991, European Nations and European Union, p. 333-362.

Challenges for European Foreign Policy in 2013, Renewing the EU's role in the world, FRIDE, A European Think Tank for Global Action, First published in Spain in 2013, www.fride.org

http://europa.eu/about-eu/basic-information/decision-making/treaties/index_en.htm

http://articles.washingtonpost.com/2013-05-15/opinions/39281707_1_european-unity-european-union-france

https://www.gov.uk/government/news/david-camerons-eu-speech--2

http://europa.eu.int/comm/enlargement/overview.htm,

${ }^{6}$ Challenges for European Foreign Policy in 2013, Renewing the EU's role in the world, FRIDE, A European Think Tank for Global Action, First published in Spain in 2013, www.fride.org 